\title{
Timing of sea ice retreat can alter phytoplankton community structure in the western Arctic Ocean
}

\author{
A. Fujiwara ${ }^{1,2}$, T. Hirawake ${ }^{2}$, K. Suzuki ${ }^{3}$, I. Imai ${ }^{2}$, and S.-I. Saitoh ${ }^{2}$ \\ ${ }^{1}$ Arctic Research Center, National Institute of Polar Research, 10-3, Midoricho, Tachikawa, Tokyo 190-8518, Japan \\ ${ }^{2}$ Faculty/Graduate School of Fisheries Sciences, 3-1-1 Minatocho, Hakodate, Hokkaido 041-8611, Japan \\ ${ }^{3}$ Faculty of Environmental Earth Science, Hokkaido University/JST-CREST, N10 W5, Kita-ku, Sapporo, \\ Hokkaido 060-0810, Japan
}

Correspondence to: A. Fujiwara (fujiwara.amane@nipr.ac.jp)

Received: 27 August 2013 - Published in Biogeosciences Discuss.: 16 September 2013

Revised: 6 February 2014 - Accepted: 18 February 2014 - Published: 1 April 2014

\begin{abstract}
This study assesses the response of phytoplankton assemblages to recent climate change, especially with regard to the shrinking of sea ice in the northern Chukchi Sea of the western Arctic Ocean. Distribution patterns of phytoplankton groups in the late summers of 2008-2010 were analysed based on HPLC pigment signatures and, the following four major algal groups were inferred via multiple regression and cluster analyses: prasinophytes, diatoms, haptophytes and dinoflagellates. A remarkable interannual difference in the distribution pattern of the groups was found in the northern basin area. Haptophytes dominated and dispersed widely in warm surface waters in 2008, whereas prasinophytes dominated in cold water in 2009 and 2010. A difference in the onset date of sea ice retreat was evident among years-the sea ice retreat in 2008 was 1-2 months earlier than in 2009 and 2010. The spatial distribution of early sea ice retreat matched the areas in which a shift in algal community composition was observed. Steel-Dwass's multiple comparison tests were used to assess the physical, chemical and biological parameters of the four clusters. We found a statistically significant difference in temperature between the haptophyte-dominated cluster and the other clusters, suggesting that the change in the phytoplankton communities was related to the earlier sea ice retreat in 2008 and the corollary increase in sea surface temperatures. Longer periods of open water during the summer, which are expected in the future, may affect food webs and biogeochemical cycles in the western Arctic due to shifts in phytoplankton community structure.
\end{abstract}

\section{Introduction}

The acceleration of warming and the shrinking of sea ice in the Arctic Ocean have been observed since the late 1990s (Steele et al., 2008; Perovich and Richter-Menge, 2009). The first dramatic sea ice reduction was observed in 2007. Thereafter, the Arctic sea ice area during the late summer has remained at similar levels as that of 2007 with a historical minimum in September 2012. Further sea ice reduction may occur, and the disappearance of summer Arctic sea ice has been predicted for the 2020s (Wang and Overland, 2009). Reductions in sea ice cover are significant on the Pacific side of the western Arctic (e.g., Perovich and Richter-Menge, 2009). Such reductions in sea ice have caused the freshening of seawater, along with a recent increase in river discharge into the Canada basin (Peterson et al., 2002; Yamamoto-Kawai et al., 2009). Corresponding to a deepening nutricline, induced by increasing volumes of low-density water, a predominance of small phytoplankton groups and reduced primary productivity can be expected in the Beaufort Sea (Li et al., 2009; McLaughlin and Carmack, 2010). On the other hand, it has been reported that a thinning or/and shrinking of sea ice enhanced underwater light availability, which stimulated higher primary productivity, where phytoplankton were not strongly limited by nutrient availability (Lee and Whitledge, 2005; Nishino et al., 2011; Arrigo et al., 2012).

Arrigo et al. (2008) showed that a longer ice-free season led to a longer algal growth season, and wider open water areas resulted in an expansion of the phytoplankton growth area. Earlier sea-ice retreat timing, which is widely occurring 
in the Arctic (Markus et al., 2009), also trigger the earlier phytoplankton bloom in some regions (Kahru et al., 2011). However, the effects of the expansion of new opened water areas and/or earlier ice retreat on phytoplankton community composition in the western Arctic remain unknown. It is important to understand the influence of sea ice reduction on phytoplankton community composition because different phytoplankton functional types such as large diatoms and small flagellates play important but different roles in biogeochemical cycles and ecosystems (e.g., Cushing 1989; Lochte et al., 1993; Sunda et al. 2002; Bopp et al., 2005; Ardyna et al., 2011; Leu et al., 2011). Therefore, we examined the surface distribution patterns of phytoplankton assemblages as derived from algal pigment data collected from the western Arctic Ocean during the late summers of 2008-2010. The main objective was to understand how the spatial variability of sea ice distribution can affect phytoplankton community composition.

\section{Materials and methods}

\subsection{Sampling and pigment analysis}

Data were collected during cruises of the R/V Mirai (Japan Agency for Marine-Earth Science and Technology), primarily in September of 2008 (28 August-6 October), 2009 (11 September-10 October) and 2010 (4 September-13 October). During these three collection years, water sampling was conducted at 185, 64 and 119 stations, respectively. Surface seawater or near-surface water (sampled at $5 \mathrm{~m}$ depth) was collected using a clean plastic bucket and Niskin bottles, which were attached to the CTD/Carousel sampler, respectively. The temperature and salinity of surface waters were measured using a thermometer and a Guildline AUTOSAL salinometer, respectively, or by a CTD system (SeaBird Electronics Inc., SBE-9plus). Nutrient concentrations $\left(\mathrm{NO}_{2}\right.$, $\mathrm{NO}_{3}, \mathrm{NH}_{4}, \mathrm{PO}_{4}$ and $\mathrm{Si}(\mathrm{OH})_{4}$ ) were determined using autoanalysers on board within $24 \mathrm{~h}$ after the sampling (Shimada, 2008; Kikuchi, 2009; Itoh, 2010). These environmental parameters were measured at all of the stations.

Water samples were collected for phytoplankton pigments at 24,15 and 37 stations, respectively, during the three cruises. For these samples, $1200-2400 \mathrm{~mL}$ of seawater were immediately filtered onto Whatman GF/F glass fiber filters $(25 \mathrm{~mm}$ in diameter) using a gentle vacuum $(<0.013 \mathrm{MPa})$. Filtered samples were stored in liquid nitrogen or a deep freezer $\left(-80^{\circ} \mathrm{C}\right)$ until analysis on land. The extraction of phytoplankton pigments followed the method of Suzuki et al. (2005), who used $N, N$-dimethylformamide with sonication. The algal pigments were separated by high-performance liquid chromatography (HPLC), following the method of Van Heukelem and Thomas (2001), except that this study used a flow rate of $1.2 \mathrm{~mL} \mathrm{~min}^{-1}$. The pigments used for the analysis were chlorophyll $c 3$ (chl $c 3$ ), peridinin (peri), 19'-hexanoyloxyfucoxanthin (hex), focuxanthin (fuco), 19'butanoyloxyfucoxanthin (but), diadinoxanthin (diadino), alloxanthin (allo), zeaxanthin (zea), prasinoxanthin (prasi), lutein (lut), chlorophyll $b$ (chl $b$ ) and chlorophyll $a$ (chl $a$ ). These pigments are often used as diagnostic pigments to identify phytoplankton community composition (e.g., Jeffrey and Vesk, 1997; Jeffrey and Wright, 2006).

Size-fractionated chl $a$ concentrations were measured using a fluorometric method with a Turner Designs 10-AU fluorometer (Welshmeyer et al., 1994) during the 2009 and 2010 cruises. The sample water was sequentially passed through Whatman Nuclepore and GF/F filters with pore sizes of 10 , 5,2 , and $0.7 \mu \mathrm{m}$, respectively. Percent contributions of sizefractionated chl $a$ detected from the each mesh size to total chl $a$ (sum of size-fractionated $\operatorname{chl} a$ ) were determined; $\% \operatorname{chl} a_{>10 \mu \mathrm{m}}, \% \mathrm{chl} a_{5-10 \mu \mathrm{m}}, \% \mathrm{chl} a_{2-5 \mu \mathrm{m}}, \% \mathrm{chl} a_{<2 \mu \mathrm{m}}$, respectively. In particular, we used sum of $\% \mathrm{chl} a_{>10 \mu \mathrm{m}}$ and $\%$ chl $a_{5-10 \mu m}$ called $F_{\mathrm{L}}$ in Fujiwara et al. (2011) for statistical analysis (Sect. 2.3) as a quantitative index of phytoplankton size structure, which is widely used as a criterion to divide phytoplankton size into two classes in the Arctic Ocean (Gosselin et al., 1997; Hill et al., 2005; Ardyna et al., 2011; Ferland et al., 2011).

\subsection{Clustering phytoplankton groups}

Multiple regression analysis (MRA) was applied to the phytoplankton pigment data to determine the most predominant phytoplankton group at each sampling station. MRA can assess the contributions of accessory pigment to chl $a$ levels (Wright and Jeffrey, 2006) and does not require any assumptions about the pigment ratios of each algal group, as does Chemical Taxonomy (CHEMTAX) (Mackey et al., 1996). Although MRA cannot discriminate among taxonomic groups that have diagnostic pigments in common (e.g., prasinophytes and chlorophytes both contain $\operatorname{chl} b$ ), it is sufficient to infer important phytoplankton groups fully comparing with previous studies in the same region (e.g., Booth and Horner, 1997; Vidussi et al., 2004; Hill et al., 2005; Sukhanova et al., 2009; Joo et al., 2012; Coupel et al., 2012). In this study, MRA was conducted twice using the following method: the first MRA included all pigment data, then several pigments with large standard errors $(>1.0)$ or unrealistic partial regression coefficients when compared to previous studies (e.g., Suzuki et al., 2002; Vidussi et al., 2004) were excluded and a second MRA was performed on the confined dataset. On the other hand, cluster analysis (CA) was performed to divide sampling sites into groups that have similar pigment composition, with Ward's linkage method using Euclidean distance. The same pigments used for CHEMTAX analysis for Baffin Bay, in the Arctic Ocean, by Vidussi et al. (2004) were chosen for CA because similar algal groups are expected to appear in our study region-chl $c 3$, peri, but, fuco, prasi, hex, allo, zea, lut and chl $b$. The ratios of these pigments were calculated and used for CA. Then, we inferred 
the areas contain similar taxonomic composition combination with MRA results.

\subsection{Multiple comparison test}

We conducted a multiple comparison test to examine the significant differences in environmental conditions among the phytoplankton clusters. Because a normal distribution could not be assumed for each environmental variable, the nonparametric Steel-Dwass's multiple comparison test was used with a $5 \%$ confidence interval. The environmental variables included in the test were water temperature, salinity, nutrient concentrations $\left(\mathrm{NO}_{2}, \mathrm{NO}_{3}, \mathrm{NH}_{4}, \mathrm{PO}_{4}\right.$ and $\left.\mathrm{Si}(\mathrm{OH})_{4}\right)$ and timing of sea ice retreat (described in 2.4), with chl $a$ and $F_{\mathrm{L}}$ as the algal parameters.

\subsection{Satellite data}

Daily sea ice concentration (SIC) data were collected by the Advanced Microwave Scanning Radiometer for Earth Observing System (AMSR-E) and retrieved from the National Snow and Ice Data Center (NSIDC). SIC was calculated by NASA-Team algorithm 2 (Markus and Cavalieri, 2000). A given pixel was defined as ice-free which SIC pixel values were less than $10 \%$, following Arrigo et al. (2008) and then the onset date of the sea ice retreat was defined as the first day that became ice-free. The daily sea surface temperature (SST) data collected by MODIS-Aqua were downloaded from the Goddard Space Flight Center/National Aeronautics and Space Administration (GSFC/NASA) with $9 \mathrm{~km}$ spatial resolution.

\section{Results}

\subsection{Surface distribution}

\subsubsection{Distribution of phytoplankton pigments}

The distribution of phytoplankton pigments showed similar pattern among the years. Figure 1a-c shows percentage contribution of each accessory pigment to the total pigments. In general, fuco and/or peri showed high contribution in shallow shelf region $(\sim 200 \mathrm{~m})$ and their contribution decrease along with the bathymetry increase. In contrast, $\operatorname{chl} b$ and prasi increased with the bathymetry (Fig. 1a-c). The distribution patterns were almost consistent with surface pigment composition during summer of 2002 and 2004 in the Chukchi Sea that Hill et al. (2005) reported. However, we would like to note that interannual variability of pigment distribution was found: not only prasi and chl $b$ but also hex and chl $c 3$ increased with the bathymetry in 2008 (Fig. 1a), but the pattern was not found in 2009 and 2010 (Fig. 1b and c).

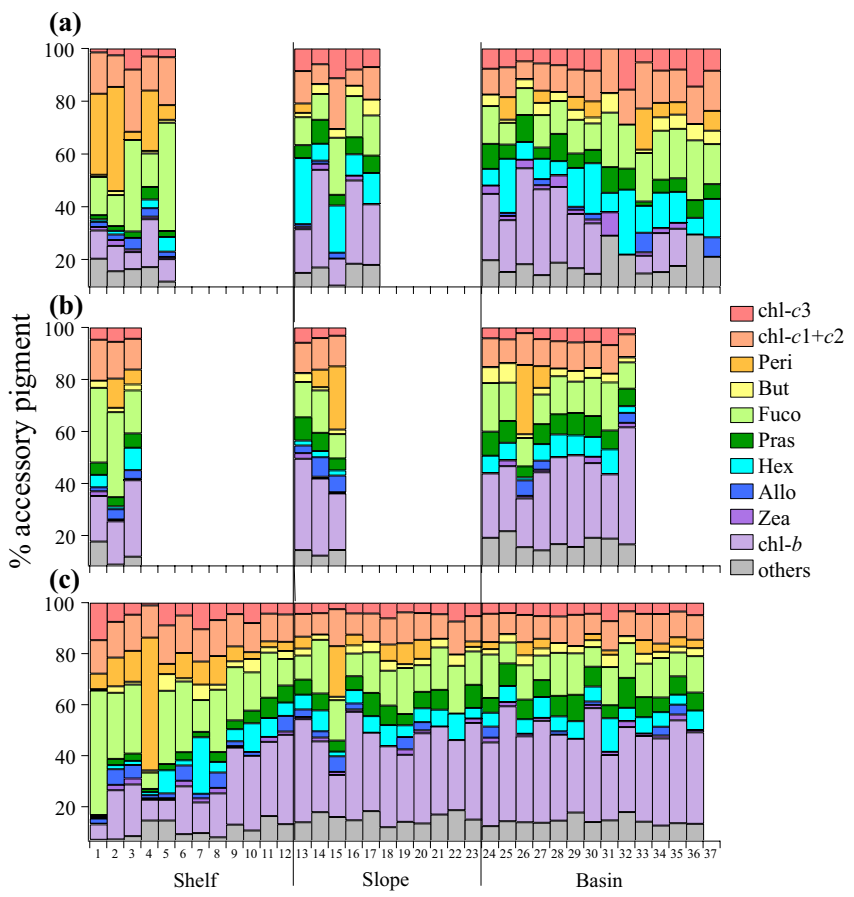

Fig. 1. Percentage contribution of major algal pigment detected by HPLC for all pigment sampled station in (a) 2008, (b) 2009 and (c) 2010. Data were sorted by station depths and divided into shelf $(\sim 200 \mathrm{~m})$, slope $(200-500 \mathrm{~m})$ and basin area $(\sim 500 \mathrm{~m})$.

\subsubsection{Inference of dominant algal groups}

Surface chl $a$ concentration of the three cruises were successfully expressed from MRA (Eq. 1), which included six accessory pigments:

$$
\begin{aligned}
\text { chl } a= & 1.49[\text { peri }]+1.85[\text { fuco }]+1.74[\text { hex }]+5.88[\text { allo }](1) \\
& +3.54[\text { zea }]+1.31[\mathrm{chl} b]+0.02,
\end{aligned}
$$

where the adjusted $R^{2}$ was 0.99 , and all partial regression coefficients of Eq. (1) were statistically significant $(\mathrm{p}<0.001$ by $t$ test and $p<0.001$ by $F$ test). Each partial coefficient was in a similar range as the reciprocals of the pigment/chl $a$ ratio reported for Baffin Bay (Vidussi et al., 2004), the North Pacific and the Bering Sea (Suzuki et al., 2002). Surface phytoplankton groups were divided into 4 clusters using $\mathrm{CA}$ and their pigment compositions. Using CA, 45, 10, 13 and 8 samples were grouped into cluster 1, 2, 3 and 4, respectively. A similarity index of 0.57 was set as the threshold for the clusters (Fig. 2). To determine the dominant phytoplankton group in each cluster, we confirmed the average pigment/chl $a$ ratio (Table 1) and the average contribution to chl $a$ of the major pigments, which was derived by MRA (Fig. 3), referring to Vidussi et al. (2004) and Hill et al. (2005), who used HPLC pigments to identify phytoplankton taxa in the Arctic Ocean.

Cluster 1 contained the highest contribution of chl $b$ relative to chl $a$ (37\%; Fig. 3). The highest prasi/chl $a$ ratio was also observed in this cluster (Table 1). The high amounts 


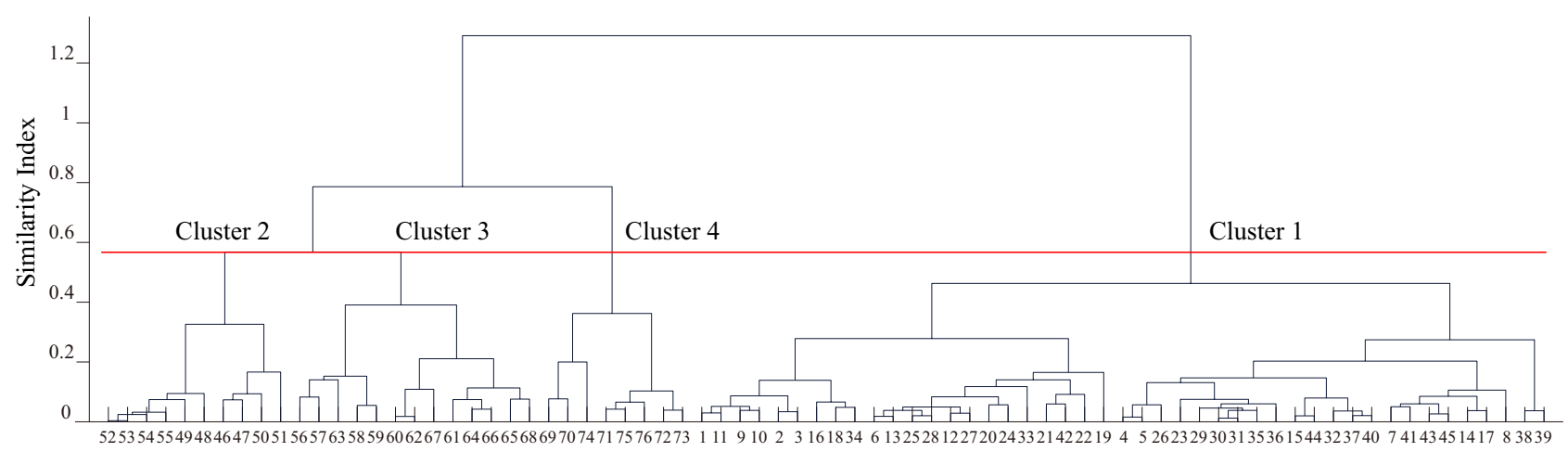

Fig. 2. Dendrogram showing phytoplankton groups that were separated by cluster analysis using pigment composition data. The red line indicates the location of the similarity index $(=0.57)$ that divided the clusters into four groups. Numbers on the $x$ axis indicate the sample IDs.

Table 1. Means and standard deviations of pigment/chl $a$ and pigment/pigment ratios and percent contribution of size fractionated chl $a$ to the total that were used in this study to determine the dominant phytoplankton groups in each cluster. Standard deviations are shown in parentheses. Note that since we obtained only one size-fractionated chl $a$ sample that classified into cluster 3, standard deviations of \%chl $a$ are not shown for cluster 3 .

\begin{tabular}{lllll}
\hline Pigment & Cluster 1 & Cluster 2 & Cluster 3 & Cluster 4 \\
\hline peri/chl $a$ & $0.023(0.025)$ & $0.060(0.025)$ & $0.041(0.036)$ & $0.249(0.105)$ \\
but/chl $a$ & $0.030(0.011)$ & $0.016(0.018)$ & $0.029(0.017)$ & $0.011(0.003)$ \\
fuco/chl $a$ & $0.125(0.034)$ & $0.25(0.072)$ & $0.122(0.037)$ & $0.096(0.022)$ \\
hex/chl $a$ & $0.060(0.022)$ & $0.025(0.026)$ & $0.129(0.060)$ & $0.014(0.006)$ \\
prasi/chl $a$ & $0.065(0.019)$ & $0.022(0.007)$ & $0.040(0.012)$ & $0.026(0.011)$ \\
zea/chl $a$ & $0.011(0.009)$ & $0.011(0.006)$ & $0.012(0.013)$ & $0.009(0.005)$ \\
lut/chl' $a$ & $0.001(0.002)$ & $0.001(0.001)$ & $0.001(0.002)$ & $0.001(0.001)$ \\
chl $b /$ chl $a$ & $0.293(0.064)$ & $0.105(0.039)$ & $0.097(0.067)$ & $0.118(0.039)$ \\
prasi/chl $b$ & $0.227(0.076)$ & $0.222(0.086)$ & $0.296(0.065)$ & $0.210(0.042)$ \\
fuco/hex & $2.37(1.24)$ & $19.4(22.5)$ & $1.30(0.965)$ & $7.79(3.93)$ \\
fuco/but & $4.76(2.50)$ & $24.8(24.3)$ & $5.03(3.28)$ & $9.73(3.84)$ \\
$\% \operatorname{chl} a_{>} 10 \mu \mathrm{m}$ & $14.9(8.71)$ & $38.5(20.27)$ & $11.0(-)$ & $46.4(19.33)$ \\
$\% \operatorname{chl} a_{5-10 \mu \mathrm{m}}$ & $6.31(4.98)$ & $16.8(7.10)$ & $7.07(-)$ & $7.50(4.32)$ \\
$\% \operatorname{chl} a_{2-5 \mu \mathrm{m}}$ & $15.6(6.11)$ & $17.7(6.79)$ & $17.2(-)$ & $12.5(5.35)$ \\
$\% \operatorname{chl} a_{<2 \mu \mathrm{m}}$ & $63.1(14.96)$ & $27.4(9.78)$ & $64.7(-)$ & $33.6(12.07)$ \\
\hline
\end{tabular}

of chl $b$ and prasi relative to chl $a$ indicated that large fractions of type I or II prasinophytes occurred in this cluster. Type I prasinophytes consist of prasinoxanthin containing Prasinophyceae, and the type II prasinophytes lack prasinoxanthin but still contain high amounts of chl $b$. An example is Micromonas pusilla, which is widely distributed throughout the Arctic (e.g., Lovejoy et al., 2006, 2007; Coupel et al., 2012). Joo et al. (2012) also found Halosphaera sp. (Prasinophyceae) was dominant on the surface in the Canada Basin during summer of 2008. Vidussi et al. (2004) reported that type I prasinophytes, type II prasinophytes and chlorophytes were the major chl $b$-containing groups in Baffin Bay. However, significantly lower lut/chl $a$ and zea/chl $a$ ratios than that of chlorophytes found in this study $(0.001 \pm 0.02$ and $0.011 \pm 0.09$, respectively) suggested that there were small fractions of chlorophytes in this cluster. Moreover, the prasi/chl $b$ ratio was within the range of type I prasinophytes (e.g., Schlüter et al., 2000; Schlüter and Møhlenberg, 2003). Therefore, we assumed that type I prasinophytes were the most dominant algal group in this cluster. The large fractions of pico-size phytoplankton chl $a\left(\% \mathrm{chl} a_{<2 \mu \mathrm{m}}\right)$ also support the inference using HPLC pigments (Table 1). On the other hand, fuco, which is a major pigment of diatoms and haptophytes, contributed $20 \%$ to chl $a$ (Fig. 3). In addition, fuco/hex $>1$ and fuco $>$ but (Table 1), which indicated that diatoms were the secondary contributors of chl $a$ (Hill et al., 2005), rather than haptophytes, in cluster 1 .

Fuco contributed the most to chl $a$ in cluster $2(\sim 45 \%$; Fig. 3). The highest values of fuco/hex and fuco/but among all clusters (Table 1) suggest that the fraction of haptophytes was relatively small compared to that of diatoms. In addition, \%chl $a_{>10 \mu \mathrm{m}}$ showed the largest contribution to the total 


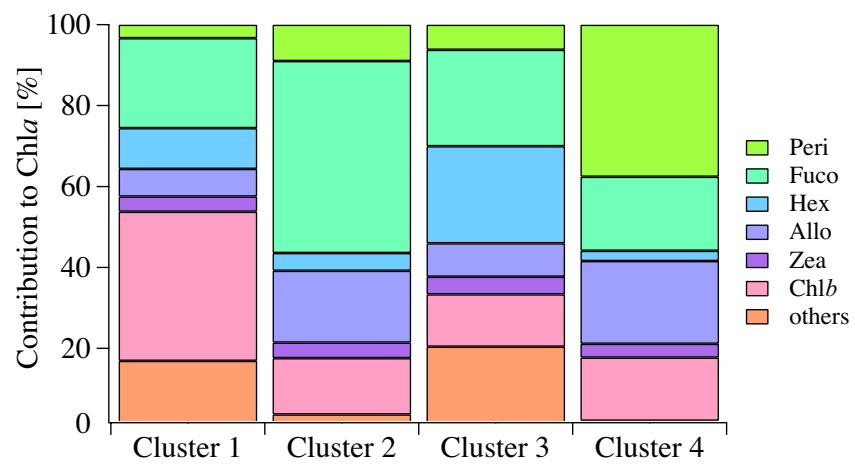

Fig. 3. Average percent contribution to chl $a$ of major algal accessory pigments for each cluster. These contributions were determined by multiple regression analysis.

chl $a$ in this cluster (Table 1). Spatial distribution of cluster 2 was roughly matched with where large sized pennate (e.g., Nitztschia spp., Flagilaria spp., Flagilariopsis spp.) and centric diatoms (e.g., Thalassiosira spp. and Chaetoceros spp.) were found (Booth and Horner, 1997; Sukhanova et al., 2009; Coupel et al., 2012). Thus, we concluded that diatoms were the dominant group in this cluster compared to that of diatoms in the clusters. On the other hand, a remarkably low fuco/chl $a$ ratio was observed $(0.25 \pm 0.072)$, compared to the result for diatoms by Suzuki et al. (2002) and Vidussi et al. (2004). The chl $b / \mathrm{chl} a$ ratio was also higher than that reported by Hill et al. (2005) in a diatom-dominated community $(0.11 \pm 0.04)$. Therefore, type I and/or II prasinophytes were the secondary groups in cluster 2 . We also noted some fractions of cryptophytes due to the $15 \%$ contribution of allo to chl $a$ (Jeffrey and Vesk, 1997). Sukahanova et al. (2009) reported cryptophytes could locally dominate in the Chukchi shelf.

Fuco and hex contributed equally to chl $a$ in cluster 3 ( $\sim 20 \%$; Fig. 3). This result suggested that a larger fraction of haptophytes was present in cluster 3 compared to other clusters (Mackey et al., 1996; Schlüter and Møhlenberg, 2003; Hill et al., 2005). The lowest fuco/hex ratio was found in this cluster (Table 1). Additionally, hex/chl $a$, but/chl $a$ and fuco/chl $a$ were within the range of type I and/or II haptophytes reported by Vidussi et al. (2004). Hence, haptophytes dominated the phytoplankton assemblages in cluster 3 . These haptophyte specific pigments can be attributed by Phaeocystis sp. or cocolithophores reported during summer in previous studies (e.g., Sukhanova et al. 2009; Joo et al., 2012; Coupel et al., 2012). However, unfortunately we could obtain only one size fractionated chl $a$ divided into cluster 3 , general size structure is yet unknown. Because the fuco/hex ratio did not always exceed 1.0, and the prasi/chl $a$ ratio was slightly higher than in clusters 2 and 4 (Table 1), some fractions of diatoms and type I prasinophytes occurred in cluster 3 .

The peri/chl $a$ ratio is a marker for dinoflagellates (e.g., Mackey et al., 1996; Jeffrey and Vesk, 1997). The maximum observed peri/chl $a$ ratio $(0.25 \pm 0.11)$ and the $\sim 30 \%$ contribution of peri to chl $a$ (Fig. 3) suggested that dinoflagellates were dominant algal group in cluster 4 . Cluster 4 was also mainly found in the shallow water as well as cluster 2 . It is consistent with the past studies that reported local dominance of dinoflagellate species such as Gymnodinium spp. and Ceratium spp. (Booth and Horner, 1997; Joo et al., 2012; Coupel et al., 2012). Large \%chl $a_{>10 \mu \mathrm{m}}$ (Table 1) also indicated the consistency of existence of the species; dinoflagellates contribute to the fraction of larger phytoplankton biomass (Booth and Horner, 1997). The chl $b / \mathrm{chl} a$ and prasi/chl $b$ ratios, which were similar to those in clusters 2 and 3, suggested that pasinophytes were the secondary groups ( $\mathrm{Ta}$ ble 1). The presence of cryptophytes was also expected based on the contribution of allo to chl $a$ (Fig. 3), but their abundance was most likely lower as estimated from MRA.

We thus inferred dominant phytoplankton groups (prasinophytes, diatoms, haptophytes and dinoflagellates) using MRA and CA. The presence of these four groups was consistent with the four major algal groups in the Arctic Ocean described by Sakshaug (2004). Secondarily, prasinophytes, cryptophytes and diatoms occurred in some fractions in the study area. Our results reveal the seasonal and spatial consistency with past studies that shows spatial distribution of phytoplankton assemblages in the western Arctic Ocean during summer (e.g., Bursa, 1963; Booth and Horner, 1997; Lovejoy et al., 2002, 2006, 2007; Sukhanova et al., 2009; Joo et al., 2012; Coupel et al., 2012).

\subsubsection{Surface distribution of phytoplankton groups, nutrients, SIC and SST}

Figures $4 \mathrm{a}-\mathrm{c}$ indicate the distributions of SIC and sea surface temperature (SST) as monitored by a satellite on September 1, 2008-2010, along with the dominant phytoplankton groups at the sea surface during the cruises in each year. The ice-edge retreated to $\sim 78^{\circ} \mathrm{N}$ throughout the study area in 2008 , except the area of $170-175^{\circ} \mathrm{W}$ (Fig. 4a). However, in 2009 and 2010, the northernmost ice edge was located at a similar latitude as in 2008, though the sea ice retreat at such a high latitude was observed only in the narrow areas of $150-155^{\circ} \mathrm{W}$ in 2009 and $160-165^{\circ} \mathrm{W}$ in 2010 (Fig. $4 \mathrm{~b}$ and c). The distribution of sea surface temperature (SST) also showed spatial variation. A relatively high $\mathrm{SST}\left(>3^{\circ} \mathrm{C}\right)$ was common in the southern Chukchi Sea $\left(\sim 72^{\circ} \mathrm{N}\right)$, where open water area commonly spread during the three years, and extended to $\sim 75^{\circ} \mathrm{N}$ in the eastern Chukchi Sea in 2008 (Fig. 4a), where ice cover was observed in 2009 and 2010 (Fig. $4 \mathrm{~b}$ and c).

The distribution of clustered phytoplankton communities was remarkably different among years and regions (Fig. 4a-c). Prasinophytes dominated the algal communities (cluster 1) mainly in the basin area of the northern Chukchi Sea and partly near the ice edge around Barrow Canyon. Diatoms and dinoflagellates, which dominated cluster 2 and 


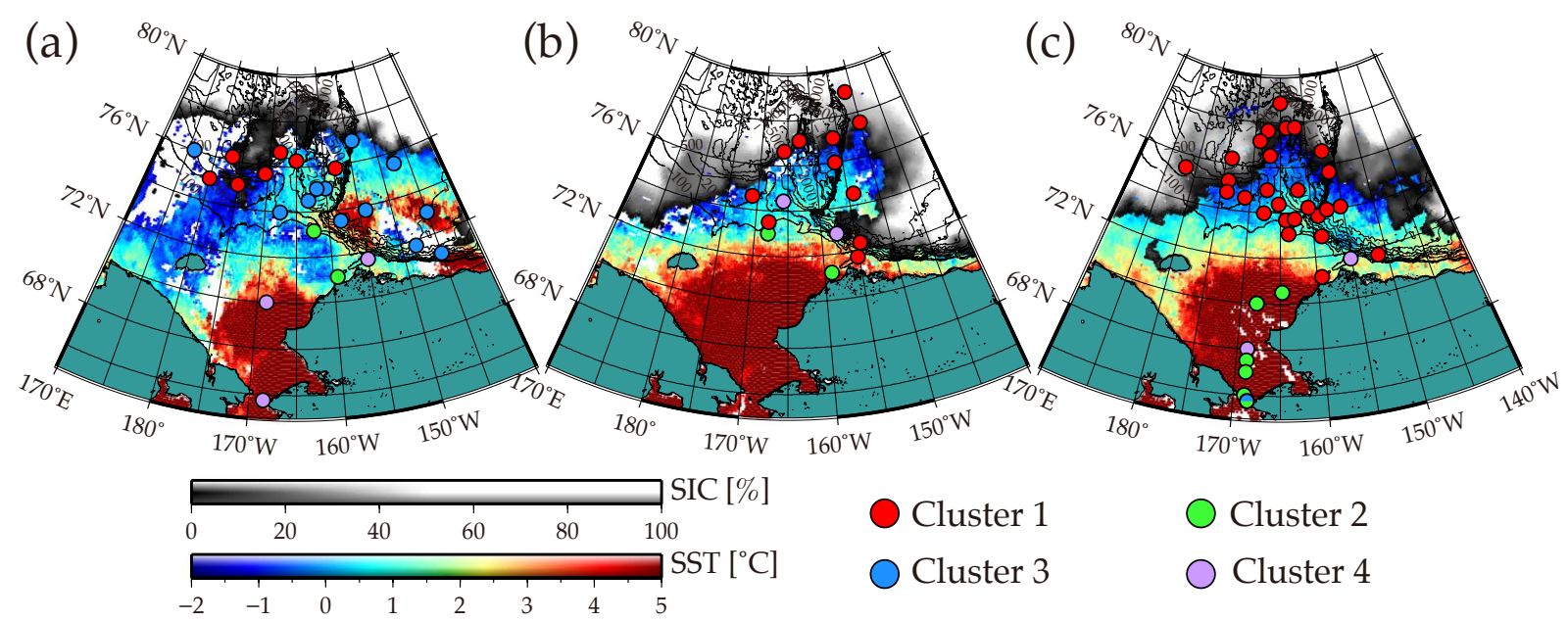

Fig. 4. Distribution of dominant phytoplankton groups at the surface layer in (a) 2008, (b) 2009 and (c) 2010. Clusters were identified by cluster analysis. SIC data were collected by AMSR-E on September 1; SST data were collected by MODIS and composited to 9-days average centred on 1 September of each year. Depth contours indicate 100-, 200-, 500-, 1000-, 1500-, and 2000-m intervals, respectively.

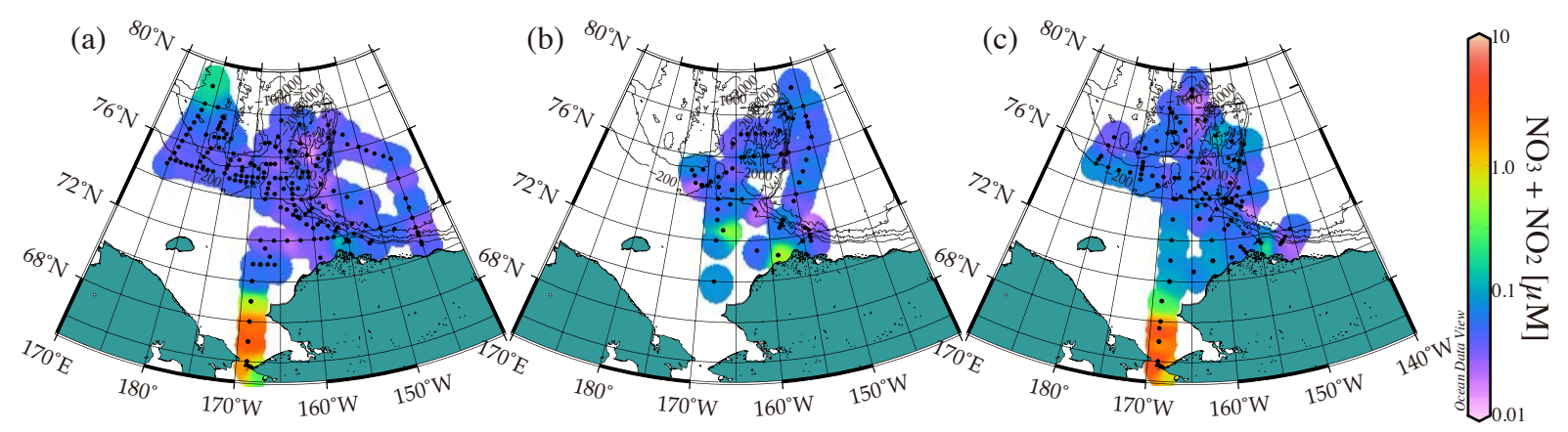

Fig. 5. Surface distribution of $\mathrm{NO}_{3}+\mathrm{NO}_{2}$ in the western Arctic Ocean during late summer in (a) 2008, (b) 2009 and (c) 2010 . Black dots indicate the sampling stations visited during the cruises. Depth contours indicate 50-, 100-, 500-, 1000- and 3000-m intervals.

4 respectively, exhibited similar horizontal distribution patterns. These clusters tended to occur in waters that extended from the shelf region of the Bering Strait to Chukchi shelf break. The most distinct interannual difference in the distribution patterns was observed in the eastern Chukchi Sea. Although clusters 1 and 3 showed a similar surface distribution pattern, most of cluster 3 was sampled in 2008 (Fig. 4a).

The surface distribution of $\mathrm{NO}_{3}+\mathrm{NO}_{2}$ concentrations sampled during the cruises is plotted in Fig. 5a-c. In contrast to the distribution of the phytoplankton groups, the horizontal distribution of surface nutrients did not vary much from year to year. In general, high concentration of $\mathrm{NO}_{3}+\mathrm{NO}_{2}(\sim 11.98 \mu \mathrm{M})$ was found in the Bering Strait and the Chukchi shelf and gradually decreased with increasing bathymetry. $\mathrm{NO}_{3}+\mathrm{NO}_{2}$ was almost depleted $(<0.1 \mu \mathrm{M})$ where bathymetry exceeded $100 \mathrm{~m}$ (Fig. 5a-c).

\subsection{Favourable environmental conditions for the phytoplankton communities}

We applied Steel-Dwass's multiple comparison test to the environmental and algal variables of the four clusters. The resulting box plots are shown in Fig. 6a-i. Statistically significant differences in temperature were observed between cluster 1 and the others. The temperature ranges observed in clusters $1,2,3$ and 4 were $-1-1^{\circ} \mathrm{C}, 1.5-3.5^{\circ} \mathrm{C}, 2.7-4.5^{\circ} \mathrm{C}$ and 3.0-5. $2^{\circ} \mathrm{C}$, respectively (Fig. 6a). Salinity differed significantly between the pairs of clusters 1 and 3 and clusters 2 and 4 (Fig. 6b). Clusters 1 and 3, in which prasinophytes and haptophytes were expected to dominate, showed lower salinity (24.5-27.5). Clusters 2 and 4, in which diatoms and dinoflagellates were expected to dominate, showed higher salinity (> 28.5). As for the chl $a$, the index of algal biomass, statistically significant differences were observed between the same pairs as for salinity (Fig. 6c). That is to say, prasinophytes and haptophytes tended to dominate with a relatively lower biomass $\left(<0.4 \mathrm{mg} \mathrm{m}^{-3}\right)$, while diatoms and dinoflagellates 

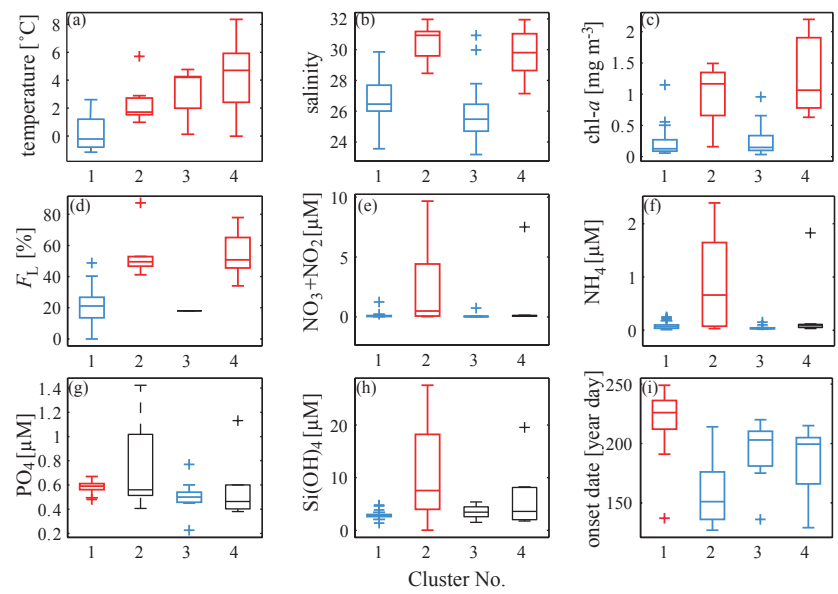

Fig. 6. Boxplots of (a) temperature, (b) salinity, (c) chl $a$, (d) $F_{\mathrm{L}}$, (e) $\mathrm{NO}_{3}+\mathrm{NO}_{2}$, (f) $\mathrm{NH}_{4}$, (g) $\mathrm{PO}_{4}$, (h) $\mathrm{Si}(\mathrm{OH})_{4}$ and (i) onset date of sea ice retreat for the four clustered phytoplankton groups. Significant differences $(p<0.05)$ were detected by Steel-Dwass's multiple comparison test between blue and red plots. Plots of the same colour and black plots are not significantly different. Note that the multiple comparison test was not conducted for $F_{\mathrm{L}}$ in cluster 3 because only one data point exists for that variable in that cluster.

tended to dominate with a higher biomass $\left(>0.8 \mathrm{mg} \mathrm{m}^{-3}\right)$ (Fig. 6c). The contribution to chl $a$ of phytoplankton cells larger than $5 \mu \mathrm{m}\left(F_{\mathrm{L}}\right)$ showed a similar pattern (Fig. 6d). Clusters 2 and 4 exhibited significantly higher fractions of large-celled phytoplankton than cluster 1 . Note that we excluded cluster 3 from the analysis because we obtained only one size-fractionated chl $a$ that sampled separated into cluster 3 . Therefore, the community size composition of cluster 3 was uncertain. Figure $6 \mathrm{e}-\mathrm{h}$ indicate the results of multiple comparison tests performed on the nutrients, $\mathrm{NO}_{3}+\mathrm{NO}_{2}$, $\mathrm{NH}_{4}, \mathrm{PO}_{4}$ and $\mathrm{Si}(\mathrm{OH})_{4}$. All nutrients except $\mathrm{PO}_{4}$ exhibited wide variation and significantly higher concentrations in cluster 2 than in the other clusters. The statistical difference of the timing of sea ice retreat observed by satellite remote sensing was also examined (Fig. 6i). We found significantly later ice retreat at the stations where the cluster 1 appeared. Note that advection of sea surface water was omitted for this analysis.

\subsection{Spatial distribution of phytoplankton communities and sea ice}

We analysed the interannual variability of SIC from 2008 to 2010 , assuming that sea ice distribution was one of the determining factors of algal taxonomic distribution. Figures $7 \mathrm{a}-\mathrm{c}$ show the distribution of sea ice on the dates that SIC became $<10 \%$, the criterion that defined the onset date of open water area (Arrigo et al., 2008). In the study area, sea ice retreat generally begins in May or June in the shelf, and the shrinking continues until August or September, when the ice edge reaches the basin. However, there was temporal and spatial variability in the onset date of sea ice retreat, especially in the eastern Chukchi Sea $\left(140-160^{\circ} \mathrm{W}\right)$, where the algal assemblages of cluster 3 were observed. The onset date in that area occurred in June in 2008 (Fig. 7a); however, sea ice retreat occurred in July and August in 2009 and 2010, respectively (Fig. $7 \mathrm{~b}$ and c). In short, 1 to 2 months earlier sea ice retreat observed in 2008 than in 2009 and 2010 (Fig. 7c and d) in the deep basin.

\section{Discussion}

\subsection{Inference of dominant phytoplankton groups}

In this study, phytoplankton assemblages at the sea surface were clustered according to similarities in pigment composition, and the dominant algal groups of each cluster were inferred. However, the community structure of phytoplankton groups cannot be determined perfectly using pigment compositions. For example, Vidussi et al. (2004) found a nonsignificant relationship between the dinoflagellate biomass estimated by counting under a microscope and the same biomass estimated using CHEMTAX. Coupel et al. (2012) is perhaps the first study that applied CHEMTAX to the western Arctic Ocean. Since they applied CHEMTAX without optimisation of initial pigment matrix, they also reported the problems of overestimation of diatoms and underestimation of nanophytoplankton biomass. They attributed this result to the presence of fuco-containing dinoflagellates and nanosized flagellates. Unfortunately, a quantitative relationship between phytoplankton pigment composition and the microscopically identified has not been established, and in addition, such data were unavailable either in this study. Nevertheless, pigment-based identification is widely used because it provides the advantage of detecting small phytoplankton, which often cannot be quantified by microscopy (Mackey et al., 1996). In fact, Hill et al. (2005) have provided important information about the surface and vertical distribution of phytoplankton assemblages in the Arctic region using composition of algal pigments. Our result was also consistent with general distribution of phytoplankton communities that Hill et al. (2005) had shown; Fuco containing assemblage increased in shallow water and chl $b$-containing flagellates was predominant in deeper water during summer (Fig. 1a-c and Fig. $4 a-c)$.

We would like to note that the most of our samplings have been conducted during typical post-bloom conditions. Large celled diatoms, e.g., Fragilariopsis, Thalasiossila, and Chaetoceros, increase their biomass, abundance and pigment concentration during spring to early summer (e.g., von Quillfeldt 2000; Sukhanova et al., 2009; Arrigo et al., 2012). Such phytoplankton bloom generally develops from June in the southern Chukchi Sea and 1 to 2 months later in the northern water (Wang et al., 2005). Toward late summer, phytoplankton biomass decrease with diatom abundance; on the 

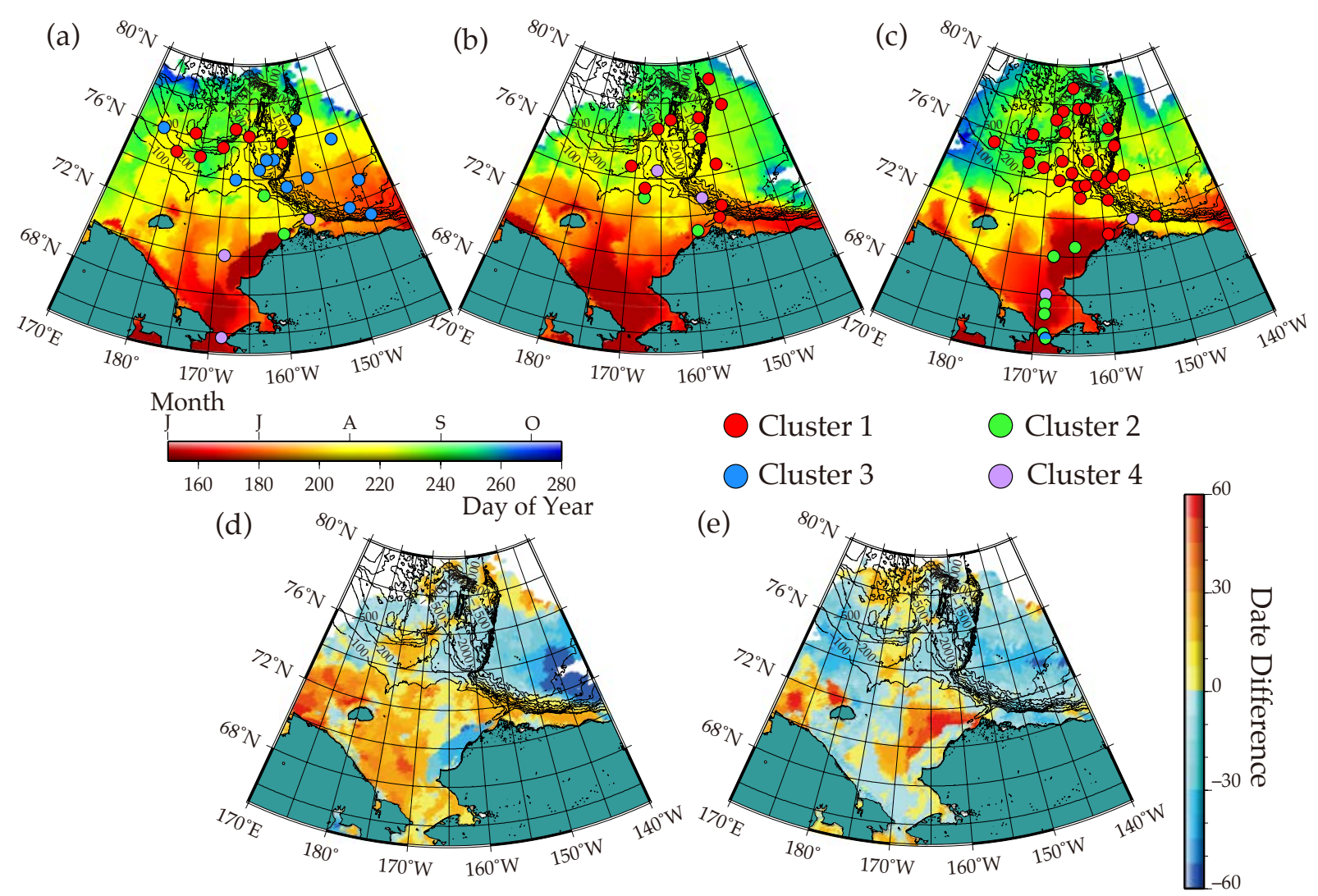

Fig. 7. Distribution of the clusters across Julian day when the area became open water in (a) 2008, (b) 2009 and (c) 2010. Clusters were identified by cluster analysis. White indicates areas where no open water appeared during the entire year. Differences of sea ice retreat timing between (d) 2008 and 2009, and between (e) 2008 and 2010 were also calculated subtracting Fig. 7b and c from Fig. 7a. Depth contours indicate 100-, 200-, 500-, 1000-, 1500-, and 2000-m intervals, respectively.

contrary dinoflagellates or nano- and pico-sized phytoplankton become predominant both in abundance and biomass in the ice-free water (Hill et al., 2005; Sukhanova et al., 2009; Joo et al., 2012; Coupel et al., 2012). Widely spread low nutrient concentration (Fig. 5) as well as low chl $a$ mainly found in the northern Chukchi Sea in this study are typical characteristics of the post-bloom (e.g., Hill et al., 2005; Ardyna et al., 2013). Some fall bloom conditions were also likely to be found where high chl $a$ and large diatoms were inferred to be dominant at surface. Inferred phytoplankton community compositions and their temporal and spatial distribution are consistent with previous reports. Thus, we believe that it is reasonable to discuss the distribution of dominant phytoplankton groups using algal pigment composition together with size-fractionated chl $a$ measurement.

\subsection{Response of phytoplankton communities to environmental conditions}

We found some significant differences among the phytoplankton clusters in terms of environmental conditions. The results of the multiple comparison test revealed that cluster 1 exhibited significantly lower temperatures than the other clusters (Fig. 6a). Clusters 1 and 3 contained less saline water than the other two clusters (Fig. 6b). Low salinity is typical of the sea ice meltwater in the Arctic Ocean (Macdonald et al., 2004). Due to a strong halocline, nutrients are generally depleted at the surface layer during summer, especially in the basin area (Fig. 5a-c). The surface distribution patterns of the dominant phytoplankton groups and nutrients showed good agreement (Fig. 4 and 5). Hill et al. (2005) reported that reproductive phytoplankton groups, such as prasinophytes and haptophytes, were prevalent at the surface instead of diatoms and dinoflagellates, which favoured nutrient-rich water. Because the western Arctic is limited in inorganic nitrogen relative to phosphorus (Yamamoto-Kawai et al., 2006), nitrogen can be a major factor limiting phytoplankton growth (e.g., Tremblay et al. 2008; 2009). Cluster 2 , which was dominated by diatoms, showed a significantly higher nitrogen level than the other clusters, which contains oligotrophic-adapted groups (Fig. 6e and f). Dinoflagellates (cluster 4) were associated with intermediate nutrient conditions and chl $a$ (Fig. 6a and e-h). Sakshaug (2004) reported a wide distribution of mixotrophic dinoflagellates such as $\mathrm{Cer}$ atium arctium and $C$. longipes in the Arctic. In short, diatoms 
and dinoflagellates with greater biomass and larger cell sizes dominated the shelf and shelf break region, where lower levels of sea-ice melt water and nutrients occurs even during the summer. In contrast, prasinophytes and haptophytes with lower biomass and/or smaller cell sizes dominated the deeper basin area (Fig. $4 \mathrm{a}-\mathrm{c}$ ), where the strong halocline due to the large volume of low-salinity water limits replenishment of nutrients from underlying waters (Fig. 5a-c). Although haptophytes are widely distributed in open oceans (Liu et al., 2009), it is interesting to note that they prefer higher temperatures compared to prasinophytes in the Arctic Ocean (Fig. 6a).

\subsection{Responses of phytoplankton groups to sea ice distribution}

Cluster 3 dominated by haptophytes was observed only in 2008 in the eastern Chukchi Sea, where prasinophytes were dominant in the other two years. To understand the reason for this difference among the years, we focused on the interannual variability of open water area and the temporal variability of the onset date of sea ice melt. As indicated in Fig. 7a-e, there were significant differences in the onset date among the three years. In particular, an earlier onset of 1 to 2 months was observed in the eastern Chukchi Sea in 2008 (Fig. 7d and e). We hypothesize that this earlier sea ice melt and longer ice-free periods reduced the ice albedo in 2008 , and warm water $\left(\sim 5^{\circ} \mathrm{C}\right)$ consequently distributed in the eastern Chukchi Sea. The locations of haptophytedominated samples showed good agreement with early open water and warm water (Figs. 4a and 7a, d and e). Such relatively warm and oligotrophic water conditions should be favourable for haptophytes (Fig. 6a, e and f). In contrast, Coupel et al. (2012) reported the high abundance of prasinophytes in the same region but one month earlier and much colder $\left(<0^{\circ} \mathrm{C}\right)$ than our observation in 2008 . Haptophytes are known as mixotrophic organisms and can survive in nutrient-depleted waters by grazing bacteria or mixotrophic nanoflagellates (Estep et al., 1986; Porter, 1988). In addition, an earlier sea ice retreat might release phytoplankton from light limitation. Under light-limited conditions, phytoplankton tend to synthesize chl $b$ and chl $a$ to increase their photosynthesis efficiency (Giesks and Kraay, 1986). In the Arctic Ocean, phytoplankton often experience light limitation due to the presence of sea ice (e.g., Sakshaug, 2004; Hill et al., 2005). Therefore, prasinophytes, which contain more chl $b$ due to low-light acclimation, are distributed widely in the Arctic. However, the longer ice-free period of 2008 may have triggered the appearance of unusual phytoplankton community that domination by haptophytes due to improved light conditions. Thus, we suggest that the dominance of haptophytes observed only in 2008 was due to the spread of warm, nutrient-depleted water and/or changing light conditions, all of which likely follow an early sea ice retreat.
Lovejoy et al. (2007) reported that, during late summer, the Arctic marine food web is supported by low temperature, low light and oligotrophic-adapted prasinophytes. Our results, however, revealed an appearance of the different community composition in area of earlier sea ice retreat; such changes in phytoplankton communities have the potential to trigger the dramatic changes in the Arctic marine food web. Reduction in sea ice is expected to increase in the future (Perovich and Richter-Menge, 2009). We note that the earlier and broader distribution of open water areas can result in a larger area in which alternation of phytoplankton community structure, from prasinophytes to haptophytes, may occur during late summer. Few studies exist showing that phytoplankton community shifts actually affect biogeochemical cycles or higher trophic levels in the western Arctic. However, a high-resolution time series observation conducted in Svalbard revealed that changes in phytoplankton community composition alter food quality for copepods (Søreide et al., 2010; Leu et al., 2011). Leu et al. (2011) revealed that phytoplankton bloom dominated by diatoms contains higher quality of polyunsaturated fatty acids (PUFAs) than other flagellates. On the other hand, it has been reported that diatoms can reduce their nutritional quality in lower nutrient conditions (Ban et al., 1997). Leu et al. (2011) also reported the importance of temporal matching between primary and secondary producers. The change of seasonal succession of phytoplankton communities due to the change of sea ice retreat timing includes risks in reproduction and growth for secondary producers. It is not yet understood what will happen if the switching of dominant algal groups from prasinophytes to haptophytes occurs in a large temporal and spatial scale. As Leu et al. (2011) have noted, process studies are the only way to determine how the spatiotemporal variability of sea ice affects lower trophic levels. However, we suggest that the ecosystem can be more heterotrophic, reproductive and such season can be longer along with the appearance of mixotrophic haptophytes due to the reduction of sea ice and warming temperature in the future western Arctic. Moreover, change of community structure during late summer can co-occur with earlier phytoplankton bloom during spring because the bloom timing in the Arctic Ocean very likely to follow the timing of sea ice retreat (Kahru et al., 2010; Ji et al., 2012). Therefore, further studies are required to assess the biogeochemical and ecological impacts of the alternation of summer phytoplankton community composition in the western Arctic.

One of the limitations of present study is that we only focused on the interannual variability of surface phytoplankton communities. However, recent environmental changes of the Arctic Ocean likely to affect upper layer phytoplankton communities directly; sea-ice shrinking, rinsing temperature (Steele et al., 2008; Perovich and Richter-Menge, 2009), increase of river discharge (Peterson et al., 2002; YamamotoKawai et al., 2009). Thus, it should be pointed out the importance of favourable environment of surface phytoplankton 
communities. On the other hand, several studies revealed that the importance of subsurface chlorophyll- $a$ maxima (SCM) in the stratified Arctic Ocean which generally co-occur with nutiricline (e.g., Tremblay et al., 2008; Martin et al., 2010; Ardyna et al., 2011). SCM contributes up to $90 \%$ of water column integrated primary production in the highly stratified and oligotrophic Arctic (Hill et al., 2013). Phytoplankton community composition is also known to be different between the two layers; pico-sized communities generally dominated at surface but larger phytoplankton dominated at SCM in contrast (Sukhanova et al., 2009; Joo et al., 2012; Coupel et al., 2012). Thus, the ecological impact of changes of phytoplankton community and its production at the SCM is seemed to be larger than those at the surface. However, since our finding suggests that surface phytoplankton community structure can change due to the rinsing of sea surface temperature consequence of early sea ice retreat, it is likely that surface phytoplankton communities are more responsive to the temporal and spatial variability of sea ice distribution than that of SCM.

\section{Conclusions}

Our study revealed the surface distribution of major phytoplankton groups during the summer in the western Arctic and differences in the environmental conditions they favour. Because we could use in situ data from only three years, and we analysed only the surface phytoplankton pigments, variability across long periods of time and the vertical phytoplankton community structure were not evaluated here. However, our data suggest that the surface phytoplankton community structure may change due to interannual variability in the spatiotemporal distribution of sea ice. A remarkable difference was observed in the present study in regions containing significantly low nutrients and low chl $a$. By analysing longer time-series data, $\mathrm{Li}$ et al. (2009) have reported that phytoplankton community size structure is decreasing due to a deepening nutricline. In addition to their report, our findings indicate that phytoplankton community can change even in the nutrient-depleted surface water associated with early expansions of open water. In situ and satellite observations of the distribution of phytoplankton functional types are important because functional types differ in their impacts on biogeochemical cycles and/or marine food webs (e.g., Lochte et al., 1993; Sunda et al., 2002; Bopp et al., 2005). Although the impact of phytoplankton community shift on biogeochemical cycles and food webs might be small, the longer ice-free periods and larger open water areas predicted for the future (Perovich and Richter-Menge, 2009) may amplify the spatial and temporal influence of algal community shifts. Therefore, the spatiotemporal patterns and changes in phytoplankton community structure should be taken into account when assessing biogeochemical cycles and food webs in the western Arctic Ocean.
Acknowledgements. We appreciate K. Shimada, T. Kikuchi, M. Itoh-Kitamura and S. Nishino for their kind support in our sampling efforts. We are grateful to the captains and crews of R/V Mirai for their logistical support during our observation periods. We also thank the staffs of Marine Works Japan LTD. for obtaining and analysing the data for this study. We would also like to thank two anonymous reviewers for their useful comments to improve the work. We would also like to thank two anonymous reviewers for their useful comments to improve the work. Sea ice concentration data were provided by the National Snow and Ice Data Center (NSIDC) at the University of Colorado, Boulder, and sea surface temperature data were provided by GSFC/NASA. This study was supported by the Japan Society for the Promotion of Science (JSPS) and the GRENE Arctic Climate Change Research Project.

Edited by: A. Bricaud

\section{References}

Ardyna, M., Gosselin, M., Michel, C., Poulin, M., and Tremblay, J. É.: Environmental forcing of phytoplankton community structure and function in the Canadian High Arctic: contrasting oligotrophic and eutrophic regions, Mar. Ecol. Prog. Ser., 442, 3757, 2011.

Ardyna, M., Babin, M., Gosselin, M., Devred, E., Bélanger, S., Matsuoka, A., and Tremblay, J. É.: Parameterization of vertical chlorophyll $a$ in the Arctic Ocean: impact of the subsurface chlorophyll maximum on regional, seasonal, and annual primary production estimates, Biogeosciences, 10, 4383-4404, 2013, http://www.biogeosciences.net/10/4383/2013/.

Arrigo, K. R., Van Dijken, G., and Pabi, S.: Impact of a shrinking Arctic ice cover on marine primary production, Geophys. Res. Lett., 35, L19603, doi:10.1029/2008GL035028, 2008.

Arrigo, K. R., Matrai, P. A., and Van Dijken, G. L.: Primary productivity in the Arctic Ocean: Impacts of complex optical properties and subsurface chlorophyll maxima on large-scale estimates, J. Geophys. Res., 116, C11022, doi:10.1029/2011JC007273, 2011.

Arrigo, K. R., Perovich, D. K., Pickart, R. S., Brown, Z. W., Van Dijken, G. L., Lowry, K. E., Mills, M. M., Palmer, M. A., Balch, W. M., Bahr, F., Bates, N. R., Benitez-Nelson, C., Bowler, B., Brownlee, E., Ehn, J. K., Frey, K. E., Garley, R., Laney, S. R., Lubelczyk, L., Mathis, J., Matsuoka, A., Mitchell, B. G., Moore, G. W. K., Ortega-Retuerta, E., Pal, S., Polashenski, C. M., Reynolds, R. A., Schieber, B., Sosik, H. M., Stephens, M., and Swift, J. H.: Massive Phytoplankton Blooms Under Arctic Sea Ice, Science, 336, 1408-1408, 2012.

Ban, S., Burns, C., Castel, J., Chaudron, Y., Christou, E., Escribano, R., Umani, S. F., Gasparini, S., Ruiz, F. G., Hoffmeyer, M., Ianora, A., Kang, H.-K., Laabir, M., Lacoste, A., Miralto, A., Ning, X., Serge Poulet, V. R., Runge, J., Shi, J., Starr, M., Uye, S.-I., and Wang, Y.: The paradox of diatom-copepod interactions, Mar. Ecol. Prog. Ser., 157, 287-293, 1997.

Booth, B. C. and Horner, R. A.: Microalgae on the arctic ocean section, 1994: species abundance and biomass, Deep-Sea Res. II, 48, 1607-1622, 1997.

Bopp, L., Aumont, O., Belviso, S., and Monfray, P.: Potential impact of climate change on marine dimethyl sulfide emissions, Tellus B, 55, 11-22, 2003. 
Bursa, A.: Phytoplankton in Coastal Waters of the Arctic Ocean at Point Barrow, Alaska, Arctic, 16, 239-262, 1963.

Carmack, E., Macdonald, R., and Jasper, S.: Phytoplankton productivity on the Canadian Shelf of the Beaufort Sea, Mar. Ecol. Prog. Ser., 277, 37-50, 2004.

Coupel, P., Jin, H. Y., Joo, M., Horner, R., Bouvet, H. A., Sicre, M. A., Gascard, J. C., Chen, J. F., Garçon, V., and RuizPino, D.: Phytoplankton distribution in unusually low sea ice cover over the Pacific Arctic, Biogeosciences, 9, 4835-4850, doi:10.5194/bg-9-4835-2012, 2012.

Cushing, D. H.: A difference in structure between ecosystems in strongly stratified waters and in those that are only weakly stratified, J. Plankton Res., 11, 1-13, 1989.

Estep, K. W., Davis, P. G., Keller, M. D., and Sieburth, J. M.: How important are oceanic algal nanoflagellates in bacterivory? Limnol. Oceanogr., 31, 646-650, 1986.

Ferland, J., Ferland, J., Gosselin, M., Gosselin, M., Starr, M., and Starr, M.: Environmental control of summer primary production in the Hudson Bay system: The role of stratification, J. Mar. Syst., 88, 385-400, 2011.

Fujiwara, A., Hirawake, T., Suzuki, K., and Saitoh, S.-I.: Remote sensing of size structure of phytoplankton communities using optical properties of the Chukchi and Bering Sea shelf region, Biogeosciences, 8, 3567-3580, doi:10.5194/bg-8-3567-2011, 2011.

Gieskes, W. W. and Kraay, G. W.: Floristic and physiological differences between the shallow and the deep nanophytoplankton community in the euphotic zone of the open tropical Atlantic revealed by HPLC analysis of pigments, Mar. Biol., 91, 567-576, 1986.

Gosselin, M., Levasseur, M., Wheeler, P. A., Horner, R. A., and Booth, B. C.: New measurements of phytoplankton and ice algal production in the Arctic Ocean, Deep-Sea Res. II, 44, 16231644, 1997.

Hill, V., Cota, G., and Stockwell, D.: Spring and summer phytoplankton communities in the Chukchi and Eastern Beaufort Seas, Deep-Sea Res. II, 52, 3369-3385, 2005.

Hill, V. J., Matrai, P. A., Olson, E., Suttles, S., Steele, M., Codispoti, L. A., and Zimmerman, R. C.: Synthesis of integrated primary production in the Arctic Ocean: II. In situ and remotely sensed estimates, Prog. Oceanogr., 110, 107-125, 2013.

Itoh, M.: R/V Mirai Cruise Report MR10-05. Yokosuka: JAMSTEC, 2010.

Jeffrey, S. W. and Vesk, M.: Introduction to marine phytoplankton and their pigment signatures, in: Phytoplankton pigments in oceanography, edited by: Jeffrey, S. W., Mantoura, R. F. C., and Wright, S. W., 37-84, UNESCO Publishing, Paris, 1997.

Jeffrey, S. W. and Wright, S. W.: Photosynthetic pigments in marine microalgae: insights from cultures and the sea, in: Algal cultures, Analogues of blooms and applications, volume 1, edited by: Rao, S., Science Publishers, 2006.

Ji, R., Jin, M., and Varpe, Ø.: Sea ice phenology and timing of primary production pulses in the Arctic Ocean, Glob. Change Biol., 19, 734-741, 2013.

Joo, H., Lee, S. H., Won Jung, S., Dahms, H.-U., and Hwan Lee, J.: Latitudinal variation of phytoplankton communities in the western Arctic Ocean, Deep-Sea Res. II, 81-84, 3-17, 2012.

Kahru, M., Brotas, V., Manzano-Sarabia, M., and Mitchell, B. G.: Are phytoplankton blooms occurring earlier in the Arctic?, Glob. Change Biol., 17, 1733-1739, 2010.
Kikuchi, T.: R/V Mirai Cruise Report MR09-03. Yokosuka: JAMSTEC, 2009.

Lee, S. H. and Whitledge, T. E.: Primary and new production in the deep Canada Basin during summer 2002, Polar Biol., 28, 190197, 2005.

Leu, E., Søreide, J. E., Hessen, D. O., Falk Petersen, S., and Berge, J.: Consequences of changing sea-ice cover for primary and secondary producers in the European Arctic shelf seas: Timing, quantity, and quality, Prog. Oceanogr., 90, 18-32, 2011.

Li, W. K. W., McLaughlin, F. A., Lovejoy, C., and Carmack, E. C.: Smallest Algae Thrive As the Arctic Ocean Freshens, Science, 326, 539-539, 2009.

Lochte, K., Ducklow, H. W., Fasham, M. J. R., and Stienens, C.: Plankton succession and carbon cycling at $47^{\circ} \mathrm{N} 20^{\circ} \mathrm{W}$ during the JGOFS North Atlantic Bloom Experiment, Deep-Sea Res. II, 40, 91-114, 1993.

Lovejoy, C., Legendre, L., Martineau, M.-J., Bâcle, and von Quillfeldt, C. H.: Distribution of phytoplankton and other protists in the North Water, Deep-Sea Res. II, 49, 5027-5047, 2002

Lovejoy, C., Massana, R., and Pedros-Alio, C.: Diversity and Distribution of Marine Microbial Eukaryotes in the Arctic Ocean and Adjacent Seas, Appl. Environ. Microbiol., 72, 3085-3095, 2006.

Lovejoy, C., Vincent, W. F., Bonilla, S., Roy, S., Martineau, M.-J., Terrado, R., Potvin, M., Massana, R., and Pedrós-Alió, C.: Distribution, phylogeny, and growth of cold-adapted picoprasinophytes in Arctic Seas, J. Phycol., 43, 78-89, 2007.

Macdonald, R. W., Sakshaug, E., and Stein, R.: The Arctic Ocean: Modern Status and Recent Climate Change, in: The Organic Carbon Cycle in the Arctic Ocean, edited by: R. Stein and R. W. Macdonald, Springer-Verlag, Berlin, Germany, 6-21, 2004.

Mackey, M., Mackey, D., and Higgins, H.: CHEMTAX-A program for estimating class abundances from chemical markers: Application to HPLC measurements of phytoplankton, Mar. Ecol. Prog. Ser., 144, 265-283, 1996.

Markus, T. and Cavalieri, D. J.: An enhancement of the NASA Team sea ice algorithm, IEEE T. Geosci. Remote, 38, 13871398, 2000.

Martin, J., Tremblay, J., Gagnon, J., Tremblay, G., Lapoussière, A., Jose, C., Poulin, M., Gosselin, M., Gratton, Y., and Michel, C.: Prevalence, structure and properties of subsurface chlorophyll maxima in Canadian Arctic waters, Mar. Ecol. Prog. Ser., 412, 69-84, 2010.

McLaughlin, F. and Carmack, E. C.: Deepening of the nutricline and chlorophyll maximum in the Canada Basin interior, 2003-2009, Geophys. Res. Lett., 37, L24602, doi:10.1029/2010GL045459, 2010.

Nishino, S., Kikuchi, T., Yamamoto-Kawai, M., Kawaguchi, Y., Hirawake, T., and Itoh, M.: Enhancement/reduction of biological pump depends on ocean circulation in the sea-ice reduction regions of the Arctic Ocean, J. Oceanogr., 67, 305-314, 2011.

Perovich, D. K. and Richter-Menge, J. A.: Loss of Sea Ice in the Arctic, Annu. Rev. Marine. Sci., 1, 417-441, 2009.

Peterson, B. J., Holmes, R. M., McClelland, J. W., Vörösmarty, C. J., Lammers, R. B., Shiklomanov, A. I., Shiklomanov, I. A., and Rahmstorf, S.: Increasing River Discharge to the Arctic Ocean, Science, 298, 2171-2173, 2002.

Porter, K.: Phagotrophic phytoflagellates in microbial food webs, Hydrobiologia, 159, 89-97, 1988. 
Sakshaug, E.: Primary and Secondary Production in the Arctic Seas, in: The Organic Carbon Cycle in the Arctic Ocean, edited by: R. Stein and R. W. Macdonald, Springer-Verlag, Berlin, Germany, 57-81, 2004.

Schlüter, L. and Møhlenberg, F.: Detecting presence of phytoplankton groups with non-specific pigment signatures, J. Appl. Phycol., 15, 465-476, doi:10.1023/B:JAPH.0000004322.47413.24, 2003.

Schlüter, L., Møhlenberg, F., Havskum, H., and Larsen, S.: The use of phytoplankton pigments for identifying and quantifying phytoplankton groups in coastal areas: testing the influence of light and nutrients on pigment/chlorophyll a ratios, Mar. Ecol. Prog. Ser., 192, 49-63, 2000.

Shimada, K.: R/V Mirai Cruise Report MR08-04. Yokosuka: JAMSTEC, 2008.

Steele, M., Ermold, W., and Zhang, J.: Arctic Ocean surface warming trends over the past 100 years, Geophys. Res. Lett., 35, L06501, doi:10.1029/2007GL031651, 2008.

Sukhanova, I. N., Flint, M. V., Pautova, L. A., Stockwell, D. A., Grebmeier, J. M., and Sergeeva, V. M.: Phytoplankton of the western Arctic in the spring and summer of 2002: Structure and seasonal changes, Deep-Sea Res. II, 56, 1223-1236, 2009.

Sunda, W., Kieber, D. J., Kiene, R. P., and Huntsman, S.: An antioxidant function for DMSP and DMS in marine algae, Nature, 418, 317-320, 2002.

Suzuki, K., Minami, C., Liu, H., and Saino, T.: Temporal and spatial patterns of chemotaxonomic algal pigments in the subarctic Pacific and the Bering Sea during the early summer of 1999, Deep-Sea Res. II, 49, 5685-5704, 2002.

Suzuki, K., Hinuma, A., Saito, H., Kiyosawa, H., Liu, H., Saino, T., and Tsuda, A.: Responses of phytoplankton and heterotrophic bacteria in the northwest subarctic Pacific to in situ iron fertilization as estimated by HPLC pigment analysis and flow cytometry, Prog. Oceanogr., 64, 167-187, 2005.

Søreide, J. E., Leu, E., Berge, J., Graeve, M., and Falk-Petersen, S.: Timing of blooms, algal food quality and Calanus glacialis reproduction and growth in a changing Arctic, Glob. Change Biol., 16, 3154-3163, 2010.

Tremblay, J.-E. and Gagnon, J.: The effects of irradiance and nutrient supply on the productivity of Arctic waters: a perspective on climate change, in: Influence of Climate Change on the Changing Arctic and Sub-Arctic Conditions, edited by: Nihoul, J. J. and Kostianoy, A., Springer Netherlands, the Netherlands, 7393, 2009.
Tremblay, J.-E., Simpson, K., Martin, J., Miller, L., Gratton, Y., Barber, D., and Price, N. M.: Vertical stability and the annual dynamics of nutrients and chlorophyll fluorescence in the coastal, southeast Beaufort Sea, J. Geophys. Res., 113, C07S90, doi:10.1029/2007JC004547, 2008.

Van Heukelem, L. and Thomas, C. S.: Computer-assisted highperformance liquid chromatography method development with applications to the isolation and analysis of phytoplankton pigments, J. Chromatogr. A, 910, 31-49, 2001.

Vidussi, F., Roy, S., Lovejoy, C., Gammelgaard, M., Thomsen, H. A., Booth, B., Tremblay, J.-E., and Mostajir, B.: Spatial and temporal variability of the phytoplankton community structure in the North Water Polynya, investigated using pigment biomarkers, Can. J. Fish. Aquat. Sci., 61, 2038-2052, 2004.

von Quillfeldt, C. H.: Common Diatom Species in Arctic Spring Blooms: Their Distribution and Abundance, Botanica Marina, 43, 499-516, 2000.

Wang, J., Cota, G., and Comiso, J.: Phytoplankton in the Beaufort and Chukchi Seas: Distribution, dynamics, and environmental forcing, Deep-Sea Res. II, 52, 3355-3368, 2005.

Wang, M. and Overland, J. E.: A sea ice free summer Arctic within 30 years? Geophys. Res. Lett., 36, L07502, doi:10.1029/2009GL037820, 2009.

Welschmeyer, N.: Fluorometric analysis of chlorophyll a in the presence of chlorophyll $\mathrm{b}$ and pheopigments, Limnol. Oceanogr., 39, 1985-1992, 1994.

Wright, S. W. and Jeffrey, S. W.: Pigment Markers for Phytoplankton Production, in: The Handbook of Environmental Chemistry, vol. 2N, edited by: J. K. Volkman, Springer-Verlag, Berlin/Heidelberg, 71-104, 2006.

Yamamoto-Kawai, M., Carmack, E. C., and McLaughlin, F. A.: Nitrogen balance and Arctic throughflow, Nature, 443, p. 43, 2006

Yamamoto-Kawai, M., McLaughlin, F., Carmack, E., Nishino, S., Shimada, K., and Kurita, N.: Surface freshening of the Canada Basin, 2003-2007: River runoff versus sea ice meltwater, J. Geophys. Res., 114, 1929-2002, 2009. 